\title{
Long-term effects of the 'Exxon Valdez' oil spill: sea otter foraging in the intertidal as a pathway of exposure to lingering oil
}

\author{
James L. Bodkin ${ }^{1, *}$, Brenda E. Ballachey ${ }^{1}$, Heather A. Coletti ${ }^{3}$, George G. Esslinger ${ }^{1}$, \\ Kimberly A. Kloecker ${ }^{1}$, Stanley D. Rice ${ }^{2}$, John A. Reed ${ }^{1}{ }$, Daniel H. Monson ${ }^{1}$ \\ ${ }^{1}$ US Geological Survey, Alaska Science Center, 4210 University Drive, Anchorage, Alaska 99508 \\ ${ }^{2}$ Auke Bay Laboratory, National Marine Fisheries Service, Juneau, Alaska 99801, USA \\ ${ }^{3}$ Present address: SW Alaska Network, National Park Service, Anchorage, Alaska 99501, USA
}

\begin{abstract}
The protracted recovery of some bird and mammal populations in western Prince William Sound (WPWS), Alaska, and the persistence of spilled 'Exxon Valdez' oil in intertidal sediments, suggests a pathway of exposure to consumers that occupy nearshore habitats. To evaluate the hypothesis that sea otter (Enhydra lutris) foraging allows access to lingering oil, we contrast spatial relations between foraging behavior and documented oil distribution. We recovered archival time-depth recorders implanted in 19 sea otters in WPWS, where lingering oil and delayed ecosystem recovery are well documented. Sea otter foraging dives ranged from +2.7 to $-92 \mathrm{~m}$ below sea level (MLLW), with intertidal accounting for 5 to $38 \%$ of all foraging. On average, female sea otters made 16050 intertidal dives per year and $18 \%$ of these dives were at depths above the $+0.80 \mathrm{~m}$ tidal elevation. Males made 4100 intertidal dives per year and $26 \%$ of intertidal foraging took place at depths above the $+0.80 \mathrm{~m}$ tidal elevation. Estimated annual oil encounter rates ranged from 2 to 24 times $\mathrm{yr}^{-1}$ for females, and 2 to 4 times $\mathrm{yr}^{-1}$ for males. Exposure rates increased in spring when intertidal foraging doubled and females were with small pups. In summer 2008, we found sea otter foraging pits on 13.5 of $24.8 \mathrm{~km}$ of intertidal shoreline surveyed. Most pits (82\%) were within $0.5 \mathrm{~m}$ of the zero tidal elevation and $15 \%$ were above $0.5 \mathrm{~m}$, the level above which most (65\%) lingering oil remains. In August 2008, we detected oil above background concentrations in 18 of $41(44 \%)$ pits excavated by sea otters on beaches with prior evidence of oiling, with total PAH concentrations up to $56000 \mathrm{ng} \mathrm{g}^{-1}$ dry weight. Our estimates of intertidal foraging, the widespread presence of foraging pits in the intertidal, and the presence of oil in and near sea otter foraging pits documents a pathway of exposure from lingering intertidal oil to sea otters foraging in WPWS.
\end{abstract}

KEY WORDS: Sea otter · 'Exxon Valdez' • Oil spill • Enhydra lutris · Time-depth recorder · TDR

\section{INTRODUCTION}

The 1989 'Exxon Valdez' oil spill in Prince William Sound (PWS) and the Gulf of Alaska resulted in widespread mortality and injury among species occupying marine habitats (Spies et al. 1996). Acute effects following the spill were most apparent as direct, oil-related mortality, affecting multiple species of kelps, marine invertebrates, fishes, birds and mammals (Piatt et al. 1990, Garrott et al. 1993, Bodkin \& Udevitz 1994, Brown et al. 1996, Highsmith et al. 1996, Rice et al. 2007). Hundreds of thousands of marine birds and thousands of marine mammals died as a result of the spill (Ballachey et al. 1994, Frost et al. 1994, Piatt \& Ford 1996), along with indeterminate numbers of kelps, invertebrates and fishes. Although injury and 
mortality were evident across a wide range of taxa, it was those species that occupy or rely on nearshore habitats where oil accumulated in bays and was deposited and retained on shorelines for which acute effects were most evident (Spies et al. 1996).

Early assessment of the fate and persistence of spilled oil identified relatively high initial decay rates $\left(\sim 58 \% \mathrm{yr}^{-1}\right)$ for several years following the spill (Wolfe et al. 1994) and it was generally presumed that, as a result, long-term exposure to wildlife was of little concern (Peterson et al. 2003). In addition, claims of rapid recovery for most species that suffered acute injury were made shortly after the spill (Johnson \& Garshelis 1995, Wiens et al. 1996) and later work suggested that long term consequences of lingering oil to sea otters specifically were minimal (Harwell \& Gentile 2006, Harwell et al. 2010, Boehm et al. 2011). However, contrary to claims of rapid recovery and limited long-term effects, ample evidence accumulated in the decades since the spill has demonstrated that not all injured species and ecosystems recovered quickly, with protracted recovery particularly evident in nearshore food webs (Peterson 2001, Rice et al. 2007). Sea otter (Enhydra lutris) population recovery rates in heavily oiled western PWS (WPWS) were about half those expected, and in areas where oiling and sea otter mortality were greatest, there was no evidence of recovery through 2000 (Bodkin et al. 2002). Reduced survival rates appeared to be the proximate factor for delayed sea otter recovery (Monson et al. 2000, 2011, Ballachey et al. 2003), and food limitation was discounted as contributing to that reduced survival (Dean et al. 2002). However, failure of populations to return to pre-spill levels, although suggestive, is not necessarily indicative of failure to recover. Establishing that recovery processes are related to the spill, rather than factors independent of the spill (e.g. ecosystem shifts, or other demographic constraints) requires evidence of continuing exposure to oil.

Following initial injury assessment efforts, research to evaluate the process and progress toward recovery of injured species and ecosystems identified unexpected delays for several species that occupy nearshore habitats (Peterson et al. 2003, Rice et al. 2007). Studies directed at examining cause for delayed recovery, completed in 1999, focused on 2 marine birds - pigeon guillemots Cepphus columba and harlequin ducks Histrionicus histrionicus - and 2 mammals - sea otters and river otters Lontra canadensis (Peterson \& Holland-Bartels 2002). Each of these species exhibited both acute initial mortality from the spill and unexplained, protracted recovery. Golet et al. (2002) found that exposure to hydrocar- bons measured through the cytochrome P4501A (CYP1A) enzyme and the liver enzymes aspartate aminotransferase (AST) and lactate dehydrogenase $(\mathrm{LDH})$ were elevated in pigeon guillemots residing in oiled, compared to unoiled habitats. For harlequin ducks, reduced adult female survival was identified as the proximate cause of delayed recovery for at least a decade after the spill, and chronic exposure to lingering oil, also indicated by elevated CYP1A, was implicated as a contributing factor (Esler et al. 2002, 2010). Although evidence of continued exposure to lingering oil through the CYP1A enzyme in river otters was present in 1996, diminishing levels thereafter led Bowyer et al. (2003) to conclude that the level of exposure was insufficient to cause continued injury. Sea otters also demonstrated evidence of continued exposure to oil late into the 1990s, through elevation of a serum enzyme (GGT) associated with liver disease or injury (Lipscomb et al. 1993, Ballachey et al. 2002a, Bodkin et al. 2002). As recently as 2008, sea otters from PWS showed elevated transcription in several genes indicating possible recent and chronic exposure to organic contaminants (Miles et al. in press).

Evidence of exposure to lingering oil through metabolic pathways via CYP1A has also been documented in other nearshore species, including Barrow's goldeneye Bucephala islandica (Trust et al. 2000, Esler et al. 2011) and 2 nearshore fishes, the masked greenling Hexagrammos octogrammus, and the crescent gunnel Pholis laeta (Jewett et al. 2002). The intertidal clam Protothaca staminea, a common sea otter prey in the nearshore invertebrate food web that resides in intertidal habitats where lingering oil was present, sequestered oil in tissues and demonstrated reduced growth rates late into the 1990s (Fukuyama et al. 2000).

In 2001, Short et al. (2004) documented unexpected amounts (55600 kg over 11.3 ha) of 'Exxon Valdez' oil (EVO) remaining in intertidal habitats, primarily in sheltered bays in WPWS and particularly along the northern Knight Island archipelago. In 2003, Short et al. (2006) identified that most intertidal oil was in the mid-tidal range of +1.8 to $+2.8 \mathrm{~m}$, and that oil could be found down to the $-0.2 \mathrm{~m}$ tidal elevation (below mean lower low water [MLLW]). Further, Short et al. (2006) estimated an average probability for encountering surface or subsurface oil in the intertidal of 0.0048, within previously heavily oiled bays at Knight Island, or about 1 in 200 random sediment disturbance events, such as a sea otter excavating a foraging pit. Short et al. (2007) also found that subsurface EVO may be expected to persist for decades in some sites. 
The persistence of spilled oil in intertidal habitats in WPWS for more than a decade following the spill provides cause for concern for recovery of injured resources (Peterson et al. 2003, Short et al. 2004, 2006, Esler et al. 2010). Exposure of upper trophic level consumers to lingering oil through an invertebrate pathway has been widely recognized as a potential mechanism contributing to protracted ecosystem recovery (Dean et al. 2000, Esler et al. 2000, 2002, Fukuyama et al. 2000, Trust et al. 2000, Bodkin et al. 2002). However, empirical data quantifying use of intertidal habitats by consumers in WPWS has been lacking, leading to controversy surrounding the extent of exposure to EVO (Boehm et al. 2007, 2011, Neff et al. 2011) or the potential effects of long-term exposure (Harwell \& Gentile 2006, Harwell et al. 2010).

Sea otters rely extensively on clams (approximately $75 \%$ of diet) as prey in WPWS (Calkins 1978, Dean et al. 2002), in both intertidal and subtidal sediments, and excavations of sediments $>0.1$ to $0.5 \mathrm{~m}$ in depth can be required to obtain this prey (Nickerson 1977 , Kvitek \& Oliver 1988). Thus, intertidal foraging provides a potential pathway of exposure to oil for sea otters and other nearshore species through direct contact with oil and/or through ingestion of contaminated prey (Bodkin et al. 2002, Short et al. 2006, Boehm et al. 2008). The pits left behind by foraging sea otters are evidence of their feeding activities, and are readily quantifiable through systematic beach surveys. In addition, time-depth recorders (TDRs) implanted in sea otters (Bodkin et al. 2004) provide detailed dive records that can be used to quantify their diving behavior, particularly in relation to depth.

Our goal was to evaluate the potential for sea otters to gain exposure to EVO remaining in intertidal sediments while foraging. We use surveys of foraging pits on beaches in oiled areas of WPWS and data from TDRs implanted in sea otters residing in these areas, along with published estimates of the distribution and abundance of lingering oil (Short et al. 2006, Boehm et al. 2008), to estimate the probability that sea otters inhabiting these areas may encounter oil while foraging in intertidal habitats. We had 4 objectives: (1) describe the extent of intertidal foraging by sea otters in WPWS, (2) estimate rates at which foraging sea otters encounter lingering oil, (3) estimate the frequency of occurrence of intertidal foraging pits dug by sea otters across soft-sediment beaches at northern Knight Island, where lingering oil is most common, and (4) quantify the concentration of total polycyclic aromatic hydrocarbons (TPAH) in sediments from intertidal foraging locations.

\section{MATERIALS AND METHODS}

\section{Study area}

This research was focused in the northern Knight Island archipelago in WPWS. Sea otters were captured between Squirrel Island and Bay of Isles at Knight Island, and sea otter foraging pit surveys were conducted between Herring Bay and Bay of Isles (Fig. 1). Shoreline oiling throughout the study area was extensive in 1989 (Wolfe et al. 1994) and sea otter mortality approached $90 \%$ following the spill (Bodkin \& Udevitz 1994). This is an area where the abundance of sea otters had not recovered to pre-spill levels by 2000 (Bodkin et al. 2002) and where spilled oil persisted for more than a decade following the spill (Short et al. 2004, 2006, 2007).

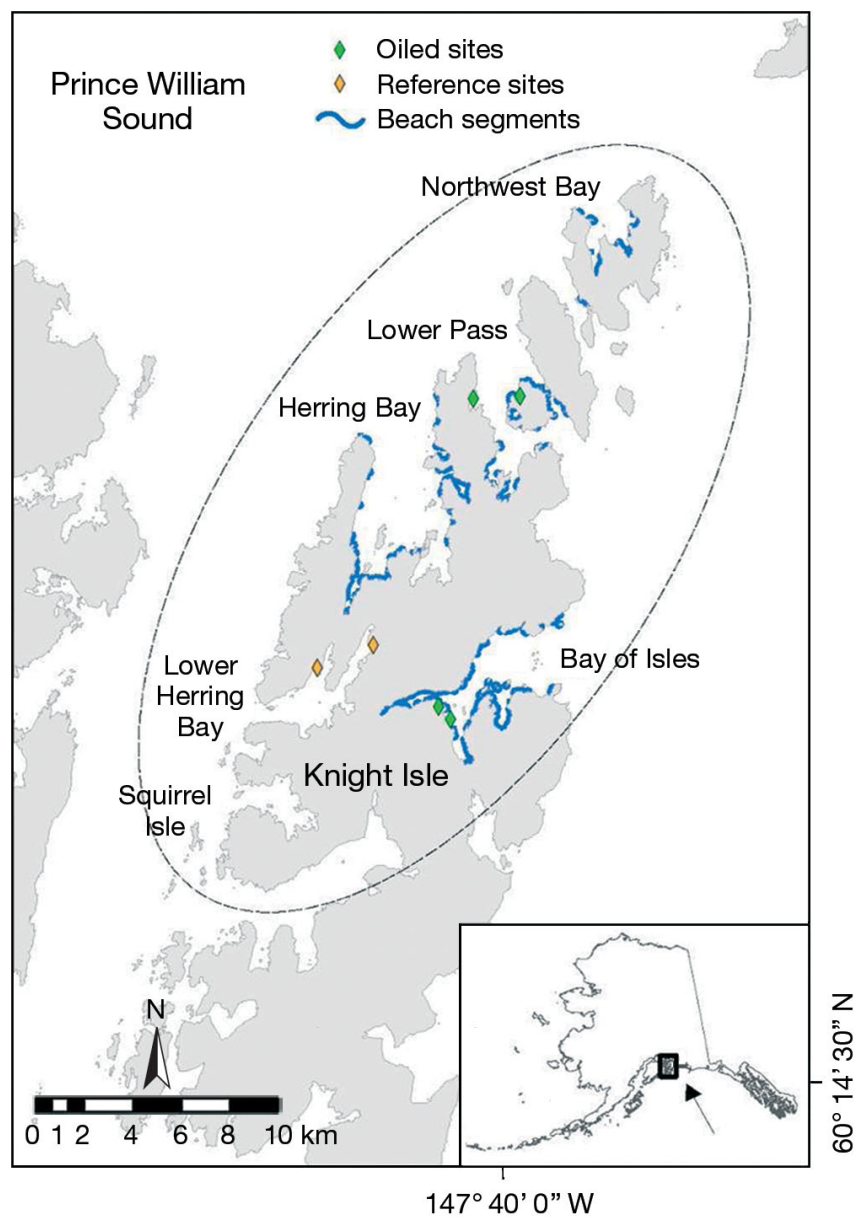

Fig. 1. Study area in the northern Knight Island archipelago of western Prince William Sound (WPWS) and locations of (1) sea otter captures (marine areas within oval), (2) sea otter pit surveys (all beaches surveyed), and (3) sediment collections (diamonds: 4 known oiled and 2 reference sites) 


\section{Foraging dive depths}

In 2003 and 2004, we captured 30 sea otters in WPWS, at northern Knight Island (Fig. 1). Sea otters were sedated (Monson et al. 2001) and a premolar tooth was extracted for age determination (Bodkin et al. 1997). We implanted adult male and female sea otters with a VHF radio and an archival TDR (Mark IX, Wildlife Computers) (Bodkin et al. 2004, 2007). VHF radio transmitters were used to obtain direct observations of otters for verification of dive types and reproductive status. TDRs were programmed to record depth at $2 \mathrm{~s}$ intervals from the time of deployment for approximately $1 \mathrm{yr}$ and were capable of storing these data for up to 10 yr. In 2004 and 2005, we attempted to recapture all of the sea otters that received TDRs in 2003 or 2004, following at least $1 \mathrm{yr}$ of data collection. We opportunistically recovered additional TDRs through 2008. Capture, handling, monitoring, and surgical procedures were approved by the Animal Care and Use Committee of the US Geological Survey, Alaska Science Center and under Federal Permit DMA-766818.

TDR data were processed with zero offset software (ZOC, Wildlife Computers) to calibrate each data point relative to the sea surface (Hooker \& Baird 2001) and through the Dive Analysis program (DA, Wildlife Computers), which transformed the $2 \mathrm{~s}$ interval depth data into individual dives using 3 userdefined values. These user-defined parameters (and values from Bodkin et al. 2004) include minimum usable dive depth $(1.5 \mathrm{~m})$, allowable surface error $(0.5 \mathrm{~m})$ and the percent of maximum depth used to define the 'bottom' (80\%). Output from DA included the following attributes for each dive: date and start time of each dive, dive duration, time at bottom, maximum depth, and mean descent and ascent rates. The variables maximum depth, dive time and bottom time, and descent and ascent rate were $\log _{10}$ transformed, and the ratio of bottom time/dive time was arcsine square root transformed to normalize distributions prior to analysis.

Among dives recorded by TDRs was a subset of dives that we observed directly. For each observed dive we recorded the date and start time of each dive along with its function as foraging or non-foraging (i.e. traveling, grooming, or interacting). We then identified these observations in the archival TDR record. Following the methods described in detail by Bodkin et al. (2004), we used this sample of known dives and their attributes (duration, bottom time and ascent/descent rates) to parameterize (Table 1) a logistic model (PROC LOGISTIC, SAS Institute),
Table 1. Parameter estimates from the logistic regression model used to classify dive types for sea otters in western Prince William Sound (WPWS), Alaska, 2003 to 2005

\begin{tabular}{|llr|}
\hline Variable & Parameter & Estimate \\
\hline$\alpha$ & $\begin{array}{l}\text { Intercept for dive type } \\
\quad \text { foraging dive }\end{array}$ & -5.8068 \\
$k_{1}$ & $\begin{array}{l}\text { Bottom time/dive duration } \\
k_{2}\end{array}$ & $\begin{array}{l}\text { Dive duration } \times \\
\text { average ascent rate }\end{array}$ \\
$k_{3}$ & $\begin{array}{c}\text { Bottom time/dive duration } \times \\
\text { average descent rate }\end{array}$ & -0.0649 \\
& & 7.8299 \\
\hline
\end{tabular}

which we then used to classify all unobserved dives as either foraging or non-foraging.

We adjusted the depth of each foraging dive by subtracting the tidal elevation at the time each dive began. Minimum low tide heights and maximum high tide heights in this area during the time of deployments ranged from -1.2 to $+4.8 \mathrm{~m}$, respectively. Tidal elevations were determined based on NOAA tide predictions for Port Audrey in WPWS, using reference station 9454050 in Cordova, Alaska (Tides and Currents, Nobeltec). Based on these tide height adjusted dive depths, each foraging dive was classified as either subtidal ( $>1.5 \mathrm{~m}$ below MLLW) or intertidal $(\leq 1.5 \mathrm{~m}$ below MLLW). The minimum dive depth defined by the DA program was $1.5 \mathrm{~m}$ and the maximum high tide was $+4.8 \mathrm{~m}$, and the highest identifiable intertidal dive was to $2.7 \mathrm{~m}$ above MLLW. Intertidal dives were classified into 7 depth bins within the intertidal zone as identified by Short et al. (2006), including $<1 \mathrm{~m}$ below MLLW, -1 to $-0.2 \mathrm{~m},-0.2$ to $+0.8 \mathrm{~m},+0.8$ to $+1.8 \mathrm{~m},+1.8$ to $+2.8 \mathrm{~m}$, +2.8 to $+3.8 \mathrm{~m}$ and +3.8 to $+4.8 \mathrm{~m}$ above MLLW. Subtidal dives were classified by depth below the water surface in $5 \mathrm{~m}$ depth bins from 0 to $100 \mathrm{~m}$. Thus, within the 0 to $5 \mathrm{~m}$ and 5 to $10 \mathrm{~m}$ true dive depth bins, the proportion of those dives to $<1.5 \mathrm{~m}$ below MLLW were sub-classified as intertidal.

\section{Foraging in intertidal habitats}

Between June and September 2008, we surveyed soft sediment beaches (grain sizes < cobble-large boulder, or $20 \mathrm{~cm}$ diameter, Wentworth scale) for evidence of sea otter foraging in the intertidal (Fig. 1). We conducted surveys during negative tide periods, beginning 15 to 30 min after the tide dropped below the MLLW level, and finishing 15 to 30 min prior to the tide rising back to MLLW. We surveyed soft sediment beaches with appropriate sediment sizes and 
visual evidence of clam presence, through shell remains. We gave each beach segment a unique ID and recorded the beginning and ending point with a GPS waypoint. At each beach segment, 2 biologists surveyed the entire region of exposed intertidal soft sediments looking for clear evidence of sea otter foraging as indicated by the presence of characteristic pits and shell litter (Kvitek \& Oliver 1988, Kvitek et al. 1988, Dean et al. 2002). When we encountered an area with 5 or more otter foraging pits, we gave it a unique pit section ID and recorded the location of each end with a GPS. Each beach segment could have 1 or more pit sections. For each pit section, we recorded the linear density of otter pits $\left(\right.$ pits $^{-1}$ ) and their elevation relative to MLLW based on tide charts. Occasionally, a group of pits was found together within a small area of a few $\mathrm{m}^{2}$ (commonly at the interface of soft sediments and rock outcrops), and for these pit sections we marked only a single GPS waypoint. During pit surveys, we also recorded evidence of surface oil on beaches and in sea otter foraging pits. This largely consisted of observations of oil sheen on pooled water, and the detection of oil through olfaction, following guidance provided by NOAA Auke Bay Laboratory staff. We did not consider tar balls on rocky surfaces nor did we excavate sediments to detect lingering oil.

\section{Sediment collections for hydrocarbon analysis}

During 29 to 31 August 2008, we collected 10 to 11 sediment samples directly from sea otter foraging pits at each of 4 beach segments where we had detected visible oil sheen in or near foraging pits during prior pit surveys in June (see above). We collected sediment samples from otter pits in the area centered on the coordinates of the sheen sighting, within a radius of approximately $20 \mathrm{~m}$. On 18 September, we collected 10 reference sediment samples from sea otter pits at each of 2 presumably unoiled beaches in Lower Herring Bay (Fig. 1).

For each sample, we used a spade to dig down approximately $15 \mathrm{~cm}$ at the center of each otter pit. With a chemically cleaned spoon, we collected approximately $170 \mathrm{~g}$ of sediment that had not been contacted by the spade. We split each sample between 2 sterile, labeled sample bottles, which were immediately closed tightly and placed in a cooler with ice. Within $2 \mathrm{~h}$, all sample bottles were sealed with electrical tape and placed in a freezer. We kept samples frozen until processing by the NOAA laboratory at Auke Bay, Alaska.

\section{Analytical methods}

Probability of intertidal diving. For each individual, we calculated the proportion of foraging dives that occurred within the intertidal zone for each week of the calendar year, and we combined these individual results to look for population level patterns in intertidal foraging over the course of a year. This was accomplished by using a binomial distribution and a logistic function to model the probability of intertidal feeding over time with week number treated as a categorical variable, which allowed the probability of intertidal feeding to change each week. The model was fit with a generalized linear model package (Proc Genmod, SAS Institute), and we included sex and reproductive state of adult females as covariates. Female reproductive states included (1) females with pups and (2) females without pups. We determined reproductive state by direct observation and by internal body temperature data obtained from the internally implanted TDRs, which can indicate estrus and parturition dates (Esslinger 2011).

Oil encounter rates. We used the combined probability (0.0048) of encountering surface or sub-surface oil in the upper and lower intertidal $(-0.2$ to $+4.8 \mathrm{~m})$ from northern Knight Island provided by Short et al. (2006), the proportion of prey in the sea otters' diet in WPWS that requires sediment excavations $(0.75$; Calkins 1978, Dean et al. 2002), and the frequency of intertidal sea otter foraging in the zone above MLLW and above the $+0.8 \mathrm{~m}$ zero tidal elevation to calculate the probability of individual sea otters encountering intertidal oil at the northern Knight Island archipelago on an annual basis.

Foraging in intertidal habitats. For each beach segment sampled, we calculated the total length of the segment and the total length of each sea otter pit section within the beach segment. Endpoints and a line connecting those for each beach segment and pit section were plotted in GIS. We also calculated the distribution of each pit segment relative to the zero tidal elevation, in $0.5 \mathrm{~m}$ intervals.

Hydrocarbon analysis of sediments. Sediment samples from sea otter foraging pits were thawed, homogenized, subsampled, spiked with $500 \mu \mathrm{l}$ of deuterated surrogate recovery standard and extracted with dichloromethane. We then dried extracts with sodium sulfate and concentrated to $1 \mathrm{ml}$ in hexane, and samples were fractionated into aliphatic and aromatic compounds on a chromatography column (6 g 100\% activated silica gel). The aliphatic compounds were eluted with $10 \mathrm{ml}$ pentane and the aromatic compounds were eluted with $20 \mathrm{ml}$ of a 1:1 
mixture of pentane and dichloromethane. Both the aliphatic and the aromatic extracts were reduced to $1 \mathrm{ml}$ in hexane, spiked with internal standards, dodecylcyclohexane and hexamethylbenzene, respectively, and stored at $-20^{\circ} \mathrm{C}$ pending analysis.

We analyzed the aromatic fractions for PAHs using a gas chromatograph equipped with a mass selective detector (GC/MSD). Concentrations were determined by the internal standard method (Short et al. 1996, Carls et al. 2004). Resultant measures were corrected for surrogate recovery. Surrogate recoveries were within acceptable limits (31 to $105 \%$ ) for all samples. Total PAH (TPAH) concentrations were calculated by summing concentrations of individual PAH.

We analyzed the aliphatic fractions for n-alkanes using a gas chromatograph equipped with a flame ionization detector (GC/FID). Analyte concentrations were determined by the internal standard method (Short et al. 1996). Surrogate recoveries were within acceptable limits (64 to $95 \%$ ) for all samples. Hydrocarbon source was inferred from PAH composition using an algorithm that summarizes 3 independent oil recognition models and 2 pyrogenic recognition models (Carls 2006).

\section{RESULTS}

\section{Foraging dive depths}

We recovered archival TDRs from 19 of 28 sea otters instrumented, consisting of 15 females and 4 males (Table 2). We documented 1957894 dives, and classified $63 \%$ of those as foraging and $37 \%$ as nonforaging (including travel, grooming, and interacting behaviors). Female sea otters made significantly more foraging dives per day (mean $=219$, range 155 to 312 ) than males (mean $=131$, range 118 to $150 ; \mathrm{p}<$ 0.01 ; Table 2), but fewer, although not significantly, non-foraging dives (108 [range 51 to 176], compared to 151 [range 58 to 259] for males).

Tidal height-adjusted foraging dive depths ranged from $+2.7 \mathrm{~m}$ above MLLW to $90 \mathrm{~m}$ below MLLW. Among individuals, most diving $(85 \%)$ occurred in water depths less than $20 \mathrm{~m}$. Although we recorded foraging dives to depths of $92 \mathrm{~m}$, less than 0.01 of foraging dives were to depths greater than $60 \mathrm{~m}$. In general, females foraged in shallower water than males. The modal depth bin for all female foraging dives was 5 to $10 \mathrm{~m}$, and 15 to $20 \mathrm{~m}$ for males (Fig. 2). Foraging also exhibited a second slight mode in the 60 to

Table 2. Enhydra lutris. Summary of data gathered from sea otters that were captured, implanted with time-depth recorders (TDRs), and recaptured ( $\mathrm{n}=19 ; 15$ females and 4 males) at Knight Island, Prince William Sound (PWS), Alaska, 2003 to 2005

\begin{tabular}{|c|c|c|c|c|c|c|c|c|}
\hline $\begin{array}{l}\text { Otter } \\
\text { ID }\end{array}$ & $\begin{array}{c}\text { Age } \\
(\mathrm{yr})\end{array}$ & $\begin{array}{c}\text { Capture } \\
\text { weight } \\
(\mathrm{kg})\end{array}$ & $\begin{array}{l}\text { Archive } \\
\text { length } \\
\text { (no. full d) }\end{array}$ & $\begin{array}{c}\text { No. of } \\
\text { dives } \\
\text { recorded }\end{array}$ & $\begin{array}{c}\text { No. of } \\
\text { foraging } \\
\text { dives }\end{array}$ & $\begin{array}{c}\text { Foraging } \\
\text { dives } \\
\left(\text { no. }^{-1}\right)\end{array}$ & $\begin{array}{c}\text { No. of } \\
\text { intertidal } \\
\text { dives }\end{array}$ & $\begin{array}{c}\text { Intertidal } \\
\text { dives } \\
\left(\text { no. }^{-1}\right)\end{array}$ \\
\hline OrCh & 3 & 19.5 & 356 & 162098 & 111325 & 312 & 32174 & 91 \\
\hline ChPi & 3 & 20.4 & 368 & 96721 & 70158 & 190 & 5277 & 18 \\
\hline $\mathrm{ChCh}$ & 4 & 20.2 & 254 & 64232 & 47193 & 186 & 1676 & 8 \\
\hline LBPi & 5 & 20.6 & 160 & 63813 & 37949 & 237 & 7208 & 45 \\
\hline $\mathrm{AqCh}$ & 5 & 26.3 & 367 & 154415 & 89712 & 244 & 15620 & 43 \\
\hline YeGr & 6 & 20.4 & 362 & 138978 & 104988 & 289 & 31754 & 87 \\
\hline YePi & 6 & 21.3 & 362 & 115590 & 74537 & 206 & 13916 & 39 \\
\hline $\mathrm{PuCh}$ & 6 & 22.7 & 369 & 122756 & 77464 & 210 & 29771 & 82 \\
\hline ReRe & 7 & 22.7 & 362 & 112228 & 93800 & 259 & 8205 & 30 \\
\hline ChWh & 7 & 25.4 & 368 & 119273 & 62791 & 171 & 13636 & 37 \\
\hline $\mathrm{ChYe}$ & 7 & 27.7 & 368 & 93431 & 63470 & 173 & 7352 & 21 \\
\hline $\mathrm{PiCh}$ & 8 & 21.1 & 215 & 75381 & 37437 & 174 & 9317 & 44 \\
\hline PuRe & 8 & 23.4 & 362 & 126210 & 102326 & 282 & 23262 & 65 \\
\hline $\mathrm{RBCh}$ & 11 & 23.1 & 370 & 96513 & 74493 & 201 & 11838 & 34 \\
\hline GrRB & 13 & 28.6 & 143 & 33690 & 22152 & 155 & 2062 & 15 \\
\hline Total/mean & $\rho^{\prime} \mathrm{S}$ & & & 1575329 & 1069795 & 219 & 213068 & 44 \\
\hline OrYe & 8 & 32.9 & 366 & 149825 & 55035 & 150 & 3008 & 8 \\
\hline YeRe & 12 & 36.3 & 360 & 107287 & 45300 & 125 & 4083 & 12 \\
\hline $\mathrm{AqCh}$ & 12 & 37.2 & 363 & 85574 & 43175 & 118 & 4871 & 16 \\
\hline LBPi & 12 & 39 & 212 & 39879 & 27644 & 130 & 1812 & 9 \\
\hline Total/mean & $0^{\prime \prime} \mathrm{s}$ & & & 382565 & 171154 & 131 & 13774 & 11 \\
\hline Total & & & & 1957894 & 1240949 & & 226842 & \\
\hline
\end{tabular}


$70 \mathrm{~m}$ depth range in both sexes (Fig. 2) and $7 \%$ of the male foraging dives were to depths $\geq 50 \mathrm{~m}$.

Of the 1240949 foraging dives, 226842 were in the intertidal zone $(18 \%)$. However, intertidal use differed between the sexes, with intertidal dives comprising on average 19\% (SE $=2.6 \%$ ) of all foraging dives for females, and $8 \%$ ( $\mathrm{SE}=0.7 \%$ ) of all foraging dives for males. The shallowest identified intertidal dive was to $+2.7 \mathrm{~m}$ above MLLW and the deepest was to $1.5 \mathrm{~m}$ below MLLW. On average, sea otters made 37 dives in the intertidal zone each day, but intertidal use varied widely by individual, ranging from 8 to 91 dives per day. Females foraged significantly more in the intertidal (mean value $=44$ dives $\mathrm{d}^{-1}$ ) than males (mean value $=11$ dives $\mathrm{d}^{-1}$, rank sum test $T=$ $14.0, \mathrm{p}<0.05$ ), and had a higher maximum number of identified intertidal dives recorded in $1 \mathrm{~d}$ (mean maximum $=236$; range 54 to 352 for females, and mean maximum $=107$; range 74 to 156 for males). Within the intertidal zone, female foraging was centered near the MLLW tidal elevation, with $42 \%$ occurring above MLLW. Although males foraged significantly less in the intertidal than females, they tended to use higher intertidal zones than females (Fig. 3), with $56 \%$ occurring above MLLW. On average, females made 8 foraging dives per day, and males 3 , into the zone $\geq 0.8 \mathrm{~m}$ above MLLW. At the individual level, foraging dives above MLLW ranged from 3 to 38 dives per day (1146 to $13790 \mathrm{yr}^{-1}$ ) and foraging dives to $\geq+0.8 \mathrm{~m}$ above MLLW ranged from almost 2 to $>8$ dives per day (482 to $6720 \mathrm{yr}^{-1}$ ).

Presence of intertidal foraging dives in TDR records peaked in the spring, although intertidal diving occurred year-round. The broad, pronounced peak in the frequency of intertidal foraging extended from Wk 12 of the calendar year (about 26 March) to Wk 26 for females (about 2 July) and Wk 20 for males (about 21 May) (Fig. 4). A second peak in intertidal foraging was evident in females beginning in midSeptember and extending through late January.

\section{Oil encounter rates}

Based on the frequency of intertidal foraging and the probability of encountering oil (Short et al. 2006),

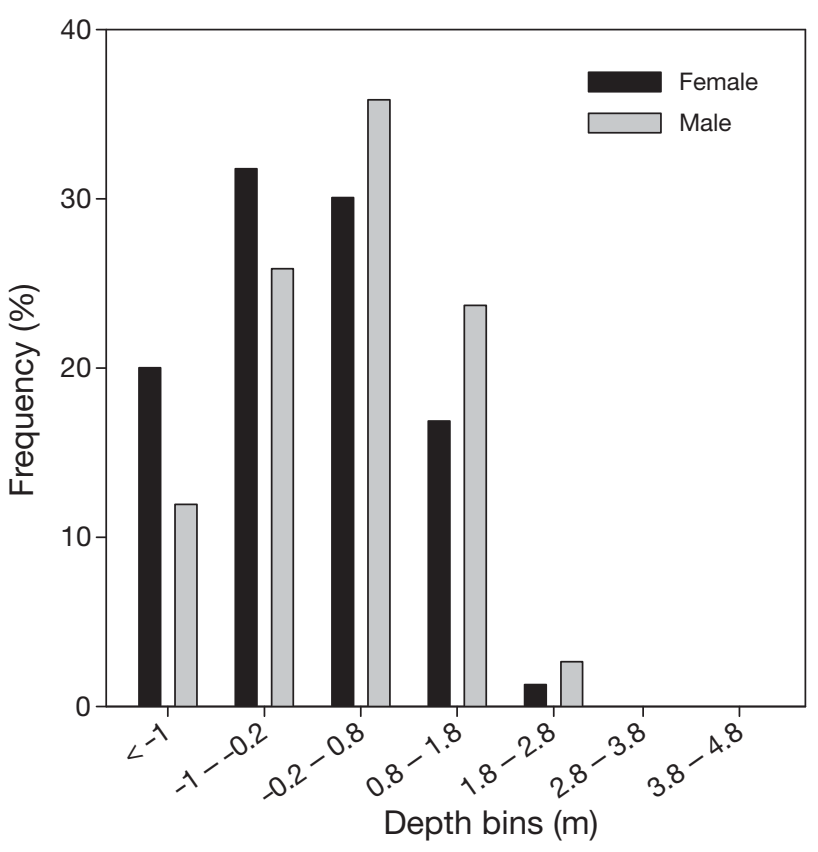

Fig. 3. Enhydra lutris. Distribution of female and male sea otter foraging depths within the intertidal zone in Prince William Sound (PWS), Alaska. $\mathrm{n}=15$ females (213 068 dives) and 4 males (13 774 dives)

we estimated that a sea otter foraging at northern Knight Island would encounter lingering EVO on average 10 times each year (range 2 to 24) (Fig. 5). Females were 2.5 times more likely to encounter lin- 
gering oil than males, with females averaging 10 encounters per year (range 2 to 24 ) and males averaging 4 encounters per year (range 2 to 5). Maximum estimated oil encounter rates, assuming an equal probability (0.0048) of encountering oil down to the MLLW level, were about once a week and most females (11 of $15 ; 73 \%$ ) were likely to encounter oil more than once a month.

\section{Foraging in intertidal habitats}

We surveyed 277 soft sediment beach segments, totaling 24.84 linear $\mathrm{km}$, for the presence of sea otter foraging pits during summer 2008 in the northern Knight archipelago (Fig. 1). Sea otter foraging pits were encountered on $71 \%$ of the beach segments surveyed (range across sites 40 to $81 \%$; Table 3). Foraging pits were detected on $13.46 \mathrm{~km}$ of the shorelines surveyed, or $54 \%$ of the total length. The total length of individual shoreline surveyed with pits ranged from 40 to $82 \%$ of the total beach segment length. Within beach segments, we measured 331 distinct pit sections and determined the tidal elevation of that section (Table 4). Most foraging pit segments ( $86 \%$ ) were within $0.5 \mathrm{~m}$ of MLLW; about $15 \%$ were above $0.5 \mathrm{~m}$, and only $2 \%$ were observed below $-0.5 \mathrm{~m}$.

\section{Sediment hydrocarbon analysis}

There were clear indications of oil in 18 of the 41 samples collected from 4 beach segments that were identified as oiled sites (Fig. 1, Table 5). Earlier in the summer, these 4 segments were identified as having numerous sea otter pits present, and sheening was observed in or near some of the pits. The highest oil concentrations in sediments were detected at Disk Island (over 56000 ppb PAH). Complementary data (alkanes, unresolved complex mixture [UCM], phytane, and petrogenic/pyrogenic source modeling) were all greater in the 18 oiled samples and support the assignment of these 18 sediment samples as oil contaminated. Alkanes were high, and the carbon preference index that compares the odd and even ratios of alkane chains were relatively equal, in contrast to reference samples where the ratios diverged. Phytane, common in crude oil, was also greatest in

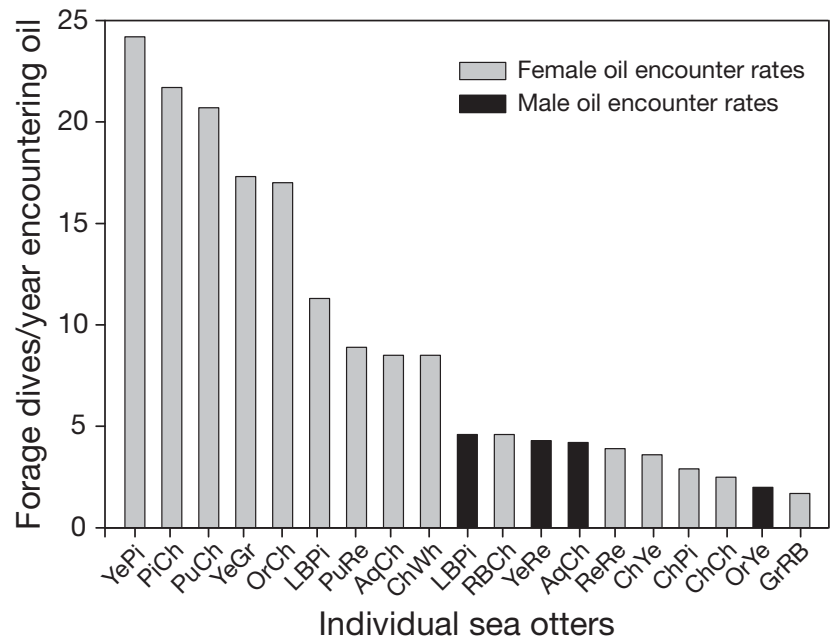

Fig. 5. Enhydra lutris. Estimated number of foraging dives per year above the $+0.8 \mathrm{~m}$ tidal elevation that encounter lingering 'Exxon Valdez' oil (EVO) for each sea otter in this study. Estimates are based on the number of foraging dives made to each zone, the probability of encountering intertidal oil (0.0048; Short et al. 2006) and the probability of foraging on prey that requires excavation (0.75; Dean et al. 2000)

oiled samples. The source modeling of petrogenic $\mathrm{PAH}$ versus pyrogenic PAH was above 4 for oiled samples, further indicating crude oil as the source, rather than a diesel or pyrogenic origin.

Reference samples from Lower Herring Bay, along with 23 samples from formerly oiled areas, were all below $50 \mathrm{ppb} \mathrm{PAH}$, and most were at or below the 
17 ppb PAH level, indicating that these samples were not contaminated. In these samples, the UCM was nearly zero, the carbon preference indices were all above 3 (indicating the alkane contributions detected are of local plant origin rather than petroleum), and the petrogenic/pyrogenic modeling was below 4, indicating that petroleum had little influence.

Disk Island had the highest percentage of oiled sediment samples (8 of 10), all of which fingerprinted consistently with EVO, and had the highest PAH concentrations (over 56000 ppb). However, even within

Table 3. Locations, lengths, and counts (n) of beach segments surveyed and sea otter foraging pit segments identified in the northern Knight Island archipelago, Prince William Sound (PWS), Alaska, 2008

\begin{tabular}{|lcccc|}
\hline Site & $\begin{array}{c}\text { Total } \\
\text { length }(\mathrm{m}) \\
\text { of beach } \\
\text { segments (n) }\end{array}$ & $\begin{array}{c}\text { Total } \\
\text { length (m) } \\
\text { of pit } \\
\text { segments (n) }\end{array}$ & $\begin{array}{c}\text { Percentage } \\
\text { of beach } \\
\text { length } \\
\text { with pits }\end{array}$ & $\begin{array}{c}\text { Percentage } \\
\text { of beach } \\
\text { segments } \\
\text { with pits }\end{array}$ \\
\hline Herring Bay & $5776(92)$ & $4725(100)$ & 82 & 71 \\
Northwest Bay & $1974(20)$ & $794(17)$ & 40 & 40 \\
Lower Passage & $4895(78)$ & $2354(80)$ & 48 & 68 \\
Bay of Isles & $12194(87)$ & $5588(134)$ & 46 & 80 \\
All & $24840(277)$ & $13461(331)$ & 54 & 71 \\
\hline
\end{tabular}

this site, concentrations were variable, ranging from background levels up to 2 samples with exceptionally high values.

\section{DISCUSSION}

Identifying recovery from large scale disturbances such as the 'Exxon Valdez' oil spill is problematic, often due to inadequate data on population abundance and trend at the time of the event, and the potential for populations to be influenced by factors independent of the event during the recovery process. Attributing delayed recovery to the spill requires at least 2 elements-evidence for continuing elevated mortality or some other demographic anomaly, and evidence for continuing exposure to oil. The former is provided by Bodkin et al. (2002) and Monson et al. (2000, 2011) and here we present evidence for the latter.

The presence of oil in intertidal sediments (Short et al. 2006, Boehm et al. 2007, Neff et al. 2011) provides a path

Table 4. Distribution of sea otter pit segments relative to tidal elevation. Data are total length of pit sections in $\mathrm{m}$, and number of pit segments (n). Percentage of total refers to segment lengths. Note that depth bins differ from those used with time-depth recorder (TDR) data

\begin{tabular}{|lcccccc|}
\hline Mean tidal elevation & Herring Bay & Northwest Bay & Lower Passage & Bay of Isles & $\begin{array}{c}\text { All sites } \\
\text { Percentage } \\
\text { of total }\end{array}$ \\
\hline$>1.5 \mathrm{~m}$ & & $49(1)$ & $94(1)$ & & $143(2)$ & 1 \\
$1.0-1.5 \mathrm{~m}$ & $3(2)$ & $154(2)$ & $111(3)$ & $1(1)$ & $269(8)$ & 2 \\
$0.5-1.0 \mathrm{~m}$ & $681(14)$ & $1(1)$ & $277(11)$ & $355(12)$ & $1315(38)$ & 10 \\
$0.0-0.5 \mathrm{~m}$ & $3283(54)$ & $517(7)$ & $1113(31)$ & $2155(51)$ & $7068(143)$ & 53 \\
$0.0--0.5 \mathrm{~m}$ & $747(29)$ & $71(5)$ & $622(28)$ & $2887(63)$ & $4457(129)$ & 33 \\
$-0.5--1.0 \mathrm{~m}$ & $11(1)$ & $1(1)$ & $78(3)$ & $188(6)$ & $278(11)$ & 2 \\
\hline
\end{tabular}

Table 5. Comparison of hydrocarbon chemistry data from 4 beach segments in formerly oiled sites (41 samples) and from 2 reference sites (20 samples) that were not directly oiled by the 'Exxon Valdez'. Means are geometric; cut off for background was $17 \mathrm{ppb}$ total PAH (TPAH), supported by the alkane data including CPI (carbon preference index), UCM (unresolved complex mixture), phytane, and source modeling (PetPyr) that identifies oil as the source when $\geq 4.0$

\begin{tabular}{|c|c|c|c|c|c|c|c|c|}
\hline & $\mathrm{n}$ & $\begin{array}{c}\text { TPAH }(1 \\
\text { Mean }\end{array}$ & $\begin{array}{l}\text { ng g }{ }^{-1} \text { dry) } \\
\text { Range }\end{array}$ & $\begin{array}{c}\text { Alkanes } \\
\text { (ng g }{ }^{-1} \text { wet) }\end{array}$ & CPI & $\mathrm{UCM}$ & Phytane & PetPy \\
\hline \multicolumn{9}{|l|}{ Oiled sites } \\
\hline Samples above background & 18 & 136 & $19-56568$ & 4289 & 1.1 & 80351 & 27.5 & 4.7 \\
\hline Samples at or below background & 23 & 8 & $3-16$ & 94 & 3.6 & 1 & 0.1 & 1.0 \\
\hline \multicolumn{9}{|l|}{ Reference sites } \\
\hline Above background & 2 & 36 & $29-46$ & 1534 & 4.5 & 0 & 0.0 & 3.2 \\
\hline At or below background & 18 & 6 & $2-15$ & 172 & 4.7 & 0 & 0.0 & 2.7 \\
\hline
\end{tabular}


through which foraging sea otters may be exposed to that oil. Some models suggest that exposure levels are so low as to provide negligible risk to sea otters (Boehm et al. 2007, Harwell et al. 2010, Neff et al. 2011). Alternatively, Bodkin et al. (2002), Monson et al. (2000, 2011), and Short et al. (2006) suggest that exposure to lingering oil may be contributing to the lack of recovery of sea otters, as has been documented for other nearshore consumers (Esler et al. 2000, 2002, 2010, 2011, Fukuyama et al. 2000, Trust et al. 2000).

\section{Foraging behavior and oil encounter rates}

Variation in foraging behavior among individuals and over time resulted in marked differences in oil exposure probabilities. Individual dietary specialization is well documented in the sea otter (Estes et al. 2003, Tinker et al. 2008), and leads to differences in foraging dive depths among individuals (Bodkin et al. 2004, this study). As a result, not all sea otters had equal probabilities of encountering oil sequestered in intertidal sediments, with more than an order of magnitude difference between the highest (24 exposures per year) and lowest frequency (2 exposures per year). A strong seasonal component to sea otter foraging behavior was evident, where across all individuals, there was a strong shift toward intertidal foraging during the last week of March. This shift was most prominent among females with small pups, who averaged over $50 \%$ intertidal foraging over a several week period that gradually declined until reaching the overall average intertidal foraging frequency of about $20 \%$ in early July. A similar pattern was evident among males, although the magnitude and span of the peak were slightly lower. This seasonal phenomenon toward intertidal foraging has not been previously described and we speculate that the pattern may be in response to a potential increase in the energy or nutrient quality of prey, particularly intertidal clams that likely enter a period of gonad development in late spring through summer (Paul \& Feder 1973, Keck et al. 1975). This is significant because estimating oil exposure risk to foraging sea otters will be influenced by seasonal patterns, and estimates that do not account for seasonality can produce biased exposure risk (e.g. Boehm et al. 2007, 2011).

\section{Assumptions}

Under the assumptions implicit in our approach, female sea otters encountered lingering oil about 10 times per year on average and males 4 times per year. We believe these estimates to be conservative for several reasons. First, the accuracy of the instruments we use is $0.25 \mathrm{~m}$ (MK IX Wildlife Computers) and the free floating placement of the instrument in the abdominal cavity required that we consider only dives below $1.5 \mathrm{~m}$ in depth. If the TDR in the sea otter does not attain a depth below the surface of $\geq 1.5 \mathrm{~m}$, those dives will not be considered in our analysis. As we have observed sea otters foraging in the intertidal or shallow subtidal without complete submersion, it is likely that our methods underestimate the frequency of intertidal foraging, compared to the subtidal. Second, we assume that only observations of prey identified as clams result in exposure potential. However, it is likely that foraging on other invertebrates such as polychaete and echiuran worms, mussels or smaller clams such as Macoma spp. also require excavations. Such prey are often unidentified and considered as 'other prey' when categorizing prey items, yet may result in unaccounted exposure potential. Third, it is possible that exposure may occur incidental to a source of disturbance in the intertidal that results in re-suspension of lingering oil, such as another foraging sea otter or wave action. Fourth, it is likely that additional exposure is gained through ingestion of prey, such as bivalves, that can accumulate tissue hydrocarbons (Fukuyama et al. 2000, Downs et al. 2002). And lastly, we do not consider the possibility of lingering oil persisting in sediments below the $0.8 \mathrm{~m}$ elevation, that if present could greatly increase encounter rates.

Alternatively, some of our assumptions may tend to overestimate the degree to which foraging in the intertidal results in exposure to residual oil. First, we assume that otters do not avoid oil sequestered in sediments and that prey distribution is independent of oil distribution. Second, we assume that the diet while foraging in the intertidal does not differ from that reported in the literature, which includes both intertidal and subtidal foraging, i.e. $75 \%$ clams. To the extent that the intertidal diet differs from the subtidal (or below MLLW), our encounter probabilities may be biased. We know of no data from our study area to evaluate this assumption. Harwell et al. (2010) suggest that some age/sex classes may forage more, or less, on clams in the intertidal compared to the subtidal. Applying the diet composition provided by Harwell et al. (2010; 33 to $67 \%$ ) would tend to reduce the frequency of oil encounter through pit excavation correspondingly. However, the lowest rate $(33 \%)$ applies to females with large pups, which are generally not present during the peak in inter- 
tidal foraging due to a highly synchronous reproductive cycle with birth taking place about the time that intertidal foraging peaks in late spring (Bodkin 2003). Additionally, the $75 \%$ clam diet reported from the observational studies we use (Calkins 1978, Dean et al. 2002) incorporates females with small pups. Perhaps more importantly, the peak in spring intertidal foraging that we observed (Fig. 4) coincides with the peak in sea otter pupping in PWS. Thus, small pups that are presumably more sensitive to oil contamination could receive similar exposure as their mother, with maximum rates of about $1 \mathrm{wk}^{-1}$.

As defined by the Exxon Valdez Oil Spill Trustee Council (Anchorage, Alaska), sea otter recovery from the spill will be complete when pre-spill abundance has been achieved and sea otters in the spill area are no longer exposed to oil. Harwell et al. (2010) revised the Short et al. (2006) estimated probability of encountering subsurface oil $(0.0037)$ by nearly an order of magnitude, to 0.00043 , and concluded that there was no plausible toxicological risk to sea otters foraging in the intertidal. When we use this lower exposure probability, our oil encounter rates in the zone above MLLW are reduced on average to $2 \mathrm{yr}^{-1}$ for females and $<1 \mathrm{yr}^{-1}$ for males. Maximum encounter rates using the more conservative encounter probability are about once every 2 mo with 5 females having encounter rates of $3 \mathrm{yr}^{-1}$ or more. Under either scenario, most sea otters, $15 \mathrm{yr}$ after the spill, are continuing to be at risk of exposure to lingering EVO, and regardless of potential toxicological effects, as defined, it is difficult to conclude that recovery of sea otters has been attained. Additionally, we suggest that mean values of exposure presented by us, or others, may not be the most meaningful metric to evaluate the potential for lingering oil to affect recovery. We consider that either reduced survival (Monson et al. 2000, in press) or increased emigration, resulting from those relatively few individuals with the highest exposure potential, would be capable of contributing to the reduced rate of sea otter recovery observed, particularly in a population that has historically demonstrated moderate growth rates (Bodkin et al. 2002, Bodkin \& Ballachey 2010).

\section{Foraging in intertidal habitats}

Our observations of sea otter foraging pits in and near beaches with visible oil, including cases of oil sheen in otter foraging pits, clearly demonstrate that not all oiled beaches are avoided by foraging sea otters. While surveying for sea otter foraging pits, we identified 11 beach segments where visible oil sheen was present in the intertidal zone, most often between the -0.5 and $+0.5 \mathrm{~m}$ tidal height. These beach segments include known oiled beaches previously sampled by Short et al. $(2004,2006)$ as well as segments not previously sampled. Additionally, sea otters and other species that occur in close proximity to oiled shores may gain exposure as disturbance events, including foraging by sea otters, mobilize sequestered intertidal oil and that oil disperses over nearshore waters.

Exposure to oil by foraging sea otters requires that lingering oil is present at the tidal elevations where they forage. Intertidal foraging by sea otters, evidenced by foraging pits, occurred along most of the shoreline we identified as potential clam habitat and surveyed at northern Knight Island, where $54 \%$ of the total shoreline length surveyed and $70 \%$ of the individual beach segments contained foraging pits. Approximately $13 \%$ of the foraging pits we located were above the $+0.5 \mathrm{~m}$ tidal elevation and $19 \%$ of the TDR-defined intertidal dives were above the +0.8 $\mathrm{m}$ elevation. Although Short et al. (2006) found that by 2003 most lingering oil at northern Knight Island was in the mid-intertidal (+1.8 to $+2.8 \mathrm{~m})$, about $36 \%$ of the subsurface oil was at tidal elevations where about 13 to $19 \%$ of intertidal sea otter foraging occurred $(<+1.8 \mathrm{~m})$. The spatial overlap between where sea otters forage in the intertidal and where lingering oil remains, and the presence of oil in foraging pits, demonstrates a clear path of exposure.

In contrast, Boehm et al. (2007) found only $1 \%$ of sea otter foraging pits at tidal elevations $\geq+0.8 \mathrm{~m}$ along known oiled shorelines at northern Knight Island in 2006. They concluded that there was little spatial overlap between the distribution of oil as measured by Short et al. $(2004,2006)$ and the distribution of sea otter foraging pits, and therefore sea otters had little risk of exposure to lingering oil through intertidal foraging. The finding of Boehm et al. (2007) that sea otters rarely foraged along known oiled shores at tidal elevations where oil remained may indicate that sea otters avoided foraging in oiled habitats. However, our observations of sea otter foraging pits with oil sheen indicated that avoidance was not universal, if at all. Additionally, the finding of evidence of exposure to lingering oil in a suite of nearshore consumers (Ballachey et al. 2002a,b, Esler et al. 2002, 2010, 2011, Jewett et al. 2002) provides additional evidence that complete avoidance may not be achieved. The conclusion made by Boehm et al. (2007) that sea otters rarely foraged in oiled intertidal habitats was based, in part, on an assumption that sea otter foraging pits 
persisted for more than a year. Recent work exploring the persistence of experimental sea otter foraging pits determined that pit persistence was affected by tidal height, with pits at higher tidal levels $(+2.0 \mathrm{~m})$ persisting on average 99 to $121 \mathrm{~d}$, whereas pits at $+1.0 \mathrm{~m}$ persisted from 124 to $160 \mathrm{~d}$, and pits at MLLW persisted from 130 to $180 \mathrm{~d}$ (Bodkin et al. 2011). As a result, our surveys in June 2008 most likely identified pits that would reflect the use of the intertidal for up to the previous 3 to 6 mo. Further, prior work that included a single visit to a site and assumed that foraging pits persisted for at least a year (Boehm et al. 2007) likely underestimated the use of the intertidal, particularly at levels above MLLW where encountering oil is more likely, and where pits are less persistent.

The overlap of lingering oil in the intertidal with intertidal foraging by sea otters provides a reasonable explanation for their slow population recovery. Contrary to initial expectations, oil persisted in significant quantities below the surface, and was first detected in extensive areas, including northern Knight Island, in 2001 surveys (Short et al. 2004). The significance of the lingering oil was heightened when the surveys were extended lower into the intertidal in 2003 surveys (Short et al. 2006), to elevations that support bivalves foraged upon by sea otters. Even in a heavily oiled area like northern Knight Island, where acute mortality was high and sea otter recovery has been slow, an average of $\sim 77$ otters have occupied the area most of the time since the spill (Dean et al. 2000, Bodkin et al. 2002). Assuming 1 pit per dive and similar diving tendencies as recorded in 2003 and 2004, this small population has dug an average of nearly 1066000 pits per year in the intertidal, and over 20 million pits in the 2 decades following the spill. This turn-over of lower and mid-intertidal sediments by foraging sea otters is a mechanism for direct exposure to lingering oil. We speculate that such excavations are likely a primary reason that reduced amounts of oil remain at these lower tidal elevations, compared to higher elevations. There should be little doubt that encounter probabilities were much higher in the years immediately following the spill when oil abundance was greater (Short et al. 2007) and extended into the lower intertidal and shallow subtidal $\left(\mathrm{O}^{\prime} \mathrm{Clair}\right.$ et al. 1996). Thus, given the sensitivity of this species to oil contamination, this exposure pathway provides a logical explanation for why the northern Knight Island sub-population, compared to other areas in PWS, had such a protracted period of population recovery (Bodkin et al. 2002) and reduced survival levels post-spill (Monson et al. 2000, 2011, Ballachey et al. 2003).

\section{Sediment hydrocarbons}

Nearly half of the sediment samples collected directly from sea otter pits were contaminated with oil. This finding of contaminated sea otter pits indicates that sea otters do not avoid shorelines harboring sub-surface oil and, more importantly, can access that oil while foraging. Most of the contaminated samples were relatively moderate in concentration, consistent with the $19 \mathrm{yr}$ of time since the spill and suggestive of chronic low-level exposure. However, 2 samples were above $54000 \mathrm{ppb}$ TPAH, in the range of the moderately oiled pits found by Short et al. (2004), where $1.1 \mathrm{~kg} \mathrm{~m}^{-2}$ of oil yielded a TPAH concentration of $68000 \mathrm{ppb}$. Concentrations of oil of this magnitude would have filled significant interstitial space in sediments, and would be sufficiently high to contaminate the fur of a sea otter excavating the pit. Oil adhering to the fur would be ingested during subsequent grooming, which could add to the energetic challenges of sea otters to cope with external contamination, as well as contributing to any long-term damages caused by TPAH toxicity.

\section{CONCLUSIONS}

We found that nearly $20 \mathrm{yr}$ after the spill, sea otters at northern Knight Island were potentially exposed to EVO on a weekly to monthly basis and that much of that exposure occurred during a time of year when relatively little observational work on diet, diving, and behavior had been done, highlighting the need to consider temporal variation in exposure potential. Further, the highest risk of exposure comes in late spring and early summer, when most adult females are giving birth. Consequently, small pups that cannot groom themselves, and are in frequent and extended contact with their mothers, may be at greater risk.

The combined evidence acquired from individualbased and temporally extended sea otter dive behavior, surveys of nearly all intertidal clam habitats within the previously heavily oiled region of northern Knight Island, and the presence of EVO in and near sea otter foraging pits provide clear documentation of a pathway of exposure from lingering intertidal oil to foraging sea otters in PWS. Exposure levels cannot be quantified, and the biological and ecological consequences of the exposure that results from the identified path are difficult to assess and largely remain unknown. However, we now know that variation in individual and seasonal dive patterns means that 
some sea otters are much more likely to be exposed to oil than others. We also know that most exposure comes at a time of year when most adult females are giving birth, and that pups have few mechanisms to avoid or mitigate exposure to oil. This pathway also provides a mechanism for disturbance to intertidal sediments where lingering oil persists, that has and will continue to contribute to the diminishment of lingering oil and thus to the process of restoration of oiled shorelines. However, a consequence of this process is the suspension of deposited oil that is likely contributing to the long-term exposure of other nearshore species to oil contamination.

Acknowledgements. This work was supported by the US Geological Survey, Alaska Science Center and the Exxon Valdez Oil Spill Trustee Council; however, the findings and conclusions do not necessarily reflect the views or position of the Trustee Council. Any use of trade names is for descriptive purposes only and does not represent endorsement by the US government. We gratefully acknowledge the assistance of J. deLaBruere, B. Hatfield, P. Kearney, M. Kenner and B. Uher-Koch for their significant contributions to sea otter captures and field data collection, to M. Murray and P. Snyder for veterinary procedures, and to J. Coffey for TDR data calibration. We appreciate the thoughtful reviews of this work by L. Bowen, D. Esler, K. Oakley, and 3 anonymous colleagues.

\section{LITERATURE CITED}

Ballachey BE, Bodkin JL, DeGange AR (1994) An overview of sea otter studies. In: Loughlin T (ed) Marine mammals and the Exxon Valdez. Academic Press, San Diego CA, p 47-59

Ballachey BE, Bodkin JL, Howlin S, Kloecker KA, Monson DH, Rebar AH, Snyder PW (2002a) Hematology and serum chemistry of sea otters in oiled and unoiled areas of Prince William Sound, Alaska, from 1996-98. Appendix BIO-01 in NVP Final Report (Project 95025-99025) Exxon Valdez Oil Spill Restoration Office, Anchorage AK, p 1-17

Ballachey BE, Stegeman JJ, Snyder PW, Blundell GW and others (2002b) Oil exposure and health of nearshore vertebrate predators in Prince William Sound following the Exxon Valdez oil spill. Chapter 2 in NVP Final Report (Project 95025-99025) Exxon Valdez Oil Spill Restoration Office, Anchorage, AK, p 1-35

Ballachey BE, Bodkin JL, Howlin S, Doroff AM, Rebar AH (2003) Correlates to survival of juvenile sea otters in Prince William Sound, Alaska. Can J Zool 81:1494-1510

Bodkin JL (2003) Sea otter. In: Feldham GA, Thompson BC, Chapman JA (eds) Wild mammals of North America. Johns Hopkins University Press, Baltimore, p 735-743

Bodkin JL, Ballachey BE (2010) Modeling the effects of mortality on sea otter populations. USGS Scientific Investigation Report 2010-5096

Bodkin JL, Udevitz MS (1994) Intersection model for estimating sea otter mortality along the Kenai Peninsula. In: Loughlin T (ed) Marine mammals and the Exxon Valdez. Academic Press, San Diego, CA, p 81-95
Bodkin JL, Ames JA, Jameson RJ, Johnson AM, Matson GM (1997) Accuracy and precision in estimating age of sea otters using cementum layers in the first premolar. J Wildl Manage 61:967-973

> Bodkin JL, Ballachey BE, Dean TA, Fukuyama AK and others (2002) Sea otter population status and the process of recovery from the 1989 'Exxon Valdez' oil spill. Mar Ecol Prog Ser 241:237-253

> Bodkin J, Esslinger GG, Monson DH (2004) Foraging depths of sea otters and implications to coastal marine communities. Mar Mamm Sci 20:305-321

> Bodkin JL, Monson DH, Esslinger GG (2007) Population status and activity budgets derived from time-depth recorders in a diving mammal. J Wildl Manage 71: 2034-2044

Bodkin JL, Reed JA, Ballachey BE (2011) Sea otter use of intertidal habitats relative to the presence of lingering oil in western Prince William Sound. Exxon Valdez Oil Spill Restoration Report. Exxon Valdez Oil Spill Trustee Council, Anchorage, Alaska

Boehm PD, Page DS, Neff JM, Johnson CB (2007) Potential for sea otter exposure to remnants of buried oil from the Exxon Valdez oil spill. Environ Sci Technol 41:6860-6867

Boehm PD, Page DS, Brown JS, Neff JM, Bragg JR, Atlas RM (2008) Distribution and weathering of crude oil residues on shorelines 18 years after the Exxon Valdez spill. Environ Sci Technol 42:9210-9216

Boehm PD, Page DS, Neff JM, Brown JS (2011) Are sea otters being exposed to subsurface intertidal oil residues from the Exxon Valdez oil spill? Mar Pollut Bull 62: 581-589

Bowyer RT, Blundell GM, Ben-David M, Jewett SC, Dean TA, Duffy LK (2003) Effects of the Exxon Valdez oil spill on river otters: Injury and recovery of a sentinel species. Wildl Monogr 153:1-53

Brown ED, Baker TT, Hose JE, Kocan RM and others (1996) Injury to the early life history stages of Pacific Herring in Prince William Sound after the Exxon Valdez oil spill. In: Rice SD, Spies RB, Wolfe DA, Wright BA (eds) Proc Exxon Valdez Oil Spill Symp. Am Fish Soc Symp 18, Bethesda, MD, p 448-462

Calkins DG (1978) Feeding behavior and major prey species of the sea otter, Enhydra lutris, in Montague Strait, Prince William Sound, Alaska. Fish Bull 76:125-131

> Carls MG (2006) Nonparametric identification of petrogenic and pyrogenic hydrocarbons in aquatic ecosystems. Environ Sci Technol 40:4233-4239

> Carls MG, Holland LG, Short JW, Heintz RA, Rice SD (2004) Monitoring polynuclear aromatic hydrocarbons in aqueous environments with passive low-density polyethylene membrane devices. Environ Toxicol Chem 23:1416-1424

> Dean TA, Bodkin JL, Jewett SC, Monson DH, Jung D (2000) Changes in sea urchins following a reduction in sea otter density as a result of the Exxon Valdez oil spill. Mar Ecol Prog Ser 199:281-291

> Dean TA, Bodkin JL, Fukuyama AK, Jewett SC, Monson DH, O'Clair CE, VanBlaricom GR (2002) Sea otter (Enhydra lutris) perspective: mechanisms of impact and potential recovery of nearshore vertebrate predators following the 1989 Exxon Valdez oil spill. Mar Ecol Prog Ser 241: 255-270

Downs CA, Shigenaka G, Fauth JE, Robinson CE, Huang A (2002) Cellular physiological assessment of bivalves after chronic exposure to spilled Exxon Valdez crude oil using a novel molecular diagnostic biotechnology. Environ Sci 
Technol 36:2987-2993

Esler D, Schmutz JA, Jarvis RL, Mulcahy DM (2000) Winter survival of adult female harlequin ducks in relation to history of contamination by the Exxon Valdez oil spill. J Wildl Manage 64:839-847

Esler D, Bowman TD, Dean TA, Trust KA, Ballachey BE, Jewett SC, O'Clair CE (2002) Harlequin duck population recovery following the Exxon Valdez oil spill: progress, process and constraints. Mar Ecol Prog Ser 241:271-286

Esler D, Trust KA, Ballachey BE, Iverson SA and others (2010) Cytochrome P4501A biomarker indication of oil exposure in harlequin ducks up to 20 years after the Exxon Valdez oil spill. Environ Toxicol Chem 29:1138-1145

Esler D, Ballachey BE, Trust KA, Iverson SA and others (2011) Cytochrome P4501A biomarker indication of the timeline of chronic exposure of Barrow's Goldeneyes to residual Exxon Valdez oil. Mar Pollut Bull 62:609-614

Esslinger GG (2011) Temporal patterns in the behavior and body temperature of sea otters in Alaska. MSc thesis, University of Alaska, Anchorage

Estes JA, Riedman ML, Staedler MM, Tinker MT, Lyon BE (2003) Individual variation in prey selection by sea otters: patterns, causes, and implications. J Anim Ecol 72: $144-155$

Frost KJ, Lowry LL, Sinclair EH, Ver Hoef J, McAllister DC (1994) Impacts on distribution, abundance, and productivity of harbor seals. In: Loughlin T (ed) Marine mammals and the Exxon Valdez. Academic Press, San Diego, CA, p 97-118

Fukuyama AK, Shigenaka G, Hoff RZ (2000) Effects of residual Exxon Valdez oil on intertidal Prototheca staminea: Mortality, growth, and bioaccumulation of hydrocarbons in transplanted clams. Mar Pollut Bull 40:1042-1050

Garrott RA, Eberhardt LL, Burn DM (1993) Mortality of sea otters in Prince William Sound following the Exxon Valdez oil spill. Mar Mamm Sci 9:343-359

Golet GH, Seiser PE, McGuire AD, Roby DR and others (2002) Long-term direct and indirect effects of the Exxon Valdez oil spill on pigeon guillemots in Prince William Sound, Alaska. Mar Ecol Prog Ser 241:287-304

> Harwell MA, Gentile JH (2006) Ecological significance of residual exposures and effects from the Exxon Valdez oil spill. Integr Environ Assess Manag 2:204-246

Harwell MA, Gentile JH, Johnson CB, Garshelis DL, Parker KR (2010) A quantitative ecological risk assessment of the toxicological risks from Exxon Valdez subsurface oil residues to sea otters at northern Knight Island, Prince William Sound, Alaska. Hum Ecol Risk Assess 16: 727-761

Highsmith RC, Rucker TL, Stekoll MS, Saupe SM, Lindeberg, MR, Jenne RN, Erickson WP (1996) Impact of the Exxon Valdez oil spill on intertidal biota. In: Rice SD, Spies RB, Wolfe DA, Wright BA (eds) Proceedings of the Exxon Valdez oil spill symposium. Am Fish Soc Symp 18. American Fisheries Society, Bethesda, p 212-237

> Hooker SK, Baird RW (2001) Diving and ranging behaviour of odontocetes: a methodological review and critique. Mammal Rev 31:81-105

Jewett SC, Dean TA, Woodin BR, Hoberg MK, Stegeman JJ (2002) Exposure to hydrocarbons ten years after the Exxon Valdez oil spill: evidence from cytochrome P4501A expression and biliary FACs in nearshore demersal fishes. Mar Environ Res 54:21-48

Johnson CB, Garshelis DL (1995) Sea otter abundance, distribution, and pup production in Prince William Sound following the Exxon Valdez oil spill. In: Wells PG, Butler JN, Hughes JS (eds) Exxon Valdez oil spill: Fate and effects in Alaskan waters. ASTM STP 1219, American Society for Testing Materials, Philadelphia, PA, p 894-929

Keck RT, Maurer D, Lind H (1975) A comparative study of the hard clam gonad developmental cycle. Biol Bull 148: 243-258

Kvitek RG, Oliver JS (1988) Sea otter foraging habits and effects on prey populations and communities in soft bottom environments. In: VanBlaricom GR, Estes JA (eds) The community ecology of sea otters. Springer-Verlag, Berlin, p 22-47

Kvitek RG, Fukuyama AK, Anderson BS, Grimm BK (1988) Sea otter foraging on deep burrowing bivalves in a California coastal lagoon. Mar Biol 98:157-167

> Lipscomb TP, Harris RK, Moeller RB, Pletcher JM, Haebler RJ, Ballachey BE (1993) Histopathologic lesions in sea otters exposed to crude oil. Vet Pathol 30:1-11

> Miles AK, Bowen L, Ballachey B, Bodkin JL and others (2012) Variations of transcript profiles between sea otters Enhydra lutris from Prince William Sound, Alaska, and clinically normal reference otters. Mar Ecol Prog Ser (in press)

> Monson DH, Doak DF, Ballachey BE, Johnson AM, Bodkin JL (2000) Long-term impacts of the Exxon Valdez oil spill on sea otters, assessed through age-dependent mortality patterns. Proc Natl Acad Sci USA 97:6562-6567

Monson DH, McCormick C, Ballachey B (2001) Chemical restraint of northern sea otters: results of past field studies. J Zoo Wildl Med 32:181-189

Monson DH, Doak DF, Ballachey BE, Bodkin JL (2011) Could residual oil from the Exxon Valdez spill create a long-term population 'sink' for sea otters in Alaska? Ecol Appl 21:2917-2932

- Neff JM, Page DS, Boehm PD (2011) Exposure of sea otters and harlequin ducks in Prince William Sound, Alaska, USA, to shoreline residues 20 years after the Exxon Valdez oil spill. Environ Toxicol Chem 30:659-672

Nickerson RB (1977) A study of the littleneck clam (Protothaca staminea Conrad) and the butter clam (Saxidomus giganteus Deshayes) in a habitat permitting coexistence, Prince William Sound, Alaska. In: Hillman RE (ed), Proceedings of the National Shellfisheries Association, Memorial Press Group, Plymouth, MA, p 85-102

O'Clair CE, Short JW, Rice SD (1996) Contamination of intertidal and subtidal sediments by oil from the Exxon Valdez in Prince William Sound. In: Rice SD, Spies RB, Wolfe DA, Wright BA (eds) Proc Exxon Valdez Oil Spill Symp. Am Fish Soc Symp 18, Bethesda, MD, p 61-93

Paul AJ, Feder HM (1973) Growth, recruitment, and distribution of the littleneck clam, Protothaca staminea, in Galena Bay, Prince William Sound, Alaska. Fish Bull 71: 665-677

> Peterson CH (2001) The Exxon Valdez oil spill in Alaska: acute, indirect, and chronic effects on the ecosystem. Adv Mar Biol 39:1-103

> Peterson CH, Holland-Bartels L (2002) Chronic impacts of oil pollution in the sea: risks to vertebrate predators. Mar Ecol Prog Ser 241:235-236

> Peterson CH, Rice SD, Short JW, Esler D, Bodkin JL, Ballachey BE, Irons DB (2003) Long-term ecosystem response to the Exxon Valdez oil spill. Science 302: 2082-2086

Piatt JF, Ford RG (1996) How many seabirds were killed by 
the Exxon Valdez oil spill? In: Rice SD, Spies RB, Wolfe DA, Wright BA (eds) Proc Exxon Valdez oil spill Symp. Am Fish Soc Symp 18, Bethesda, MD, p 712-719

Piatt JF, Lensink CF, Butler W, Kendziorek M, Nysewander DR (1990) Immediate impact of the Exxon Valdez oil spill on marine birds. Auk 107:387-397

Rice SD, Short JW, Carls MG, Moles A, Spies RB (2007) The Exxon Valdez oil spill. In: Spies RB (ed) Long-term ecological change in the Northern Gulf of Alaska. Elsevier, Amsterdam, p 419-520

Short JW, Jackson TL, Larsen ML, Wade TL (1996) Analytical methods used for the analysis of hydrocarbons in crude oil, tissues, sediments, and seawater collected for the natural resources damage assessment of the Exxon Valdez oil spill. In: Rice SD, Spies RB, Wolfe DA, Wright BA (eds) Proc Exxon Valdez oil spill Symp. Am Fish Soc Symp 18, Bethesda, MD, p 140-148

Short JW, Lindeberg MR, Harris PM, Maselko JM, Pela JJ, Rice SD (2004) Estimate of oil persisting on the beaches of Prince William Sound 12 years after the Exxon Valdez oil spill. Environ Sci Technol 38:19-25

Short JW, Maselko JM, Lindeberg MR, Harris PM, Rice SD (2006) Vertical distribution and probability of encountering intertidal Exxon Valdez oil on shorelines of three embayments within Prince William Sound, Alaska. Environ Sci Technol 40:3723-3729

Short JW, Irvine GV, Mann DH, Maselko JM and others

Editorial responsibility: Charles Peterson,

Morehead City, North Carolina, USA
(2007) Slightly weathered Exxon Valdez oil persists in Gulf of Alaska beach sediments after 16 years. Environ Sci Technol 41:1245-1250

Spies RB, Rice SD, Wolfe DA, Wright BA (1996) The effects of the Exxon Valdez oil spill on the Alaskan coastal environment. In: Rice SD, Spies RB, Wolfe DA, Wright BA (eds) Proc Exxon Valdez Oil Spill Symp. Am Fish Soc Symp 18, Bethesda, MD, p 1-16

Tinker MT, Bentall G, Estes JA (2008) Food limitation leads to behavioral diversification and dietary specialization in sea otters. Proc Natl Acad Sci USA 105:560-565

Tinker MT, Mangel M, Estes JA (2009) Learning to be different: acquired skills, social learning, frequency dependence, and environmental variation can cause behaviourally mediated foraging specializations. Evol Ecol Res 11:1-29

> Trust KA, Esler D, Woodin BR, Stegeman JJ (2000) Cytochrome P4501A induction in sea ducks inhabiting nearshore areas of Prince William Sound, Alaska. Mar Pollut Bull 40:397-403

- Wiens JA, Crist TO, Day RH, Murphy SM, Hayward GD (1996) Effects of the Exxon Valdez oil spill on marine birds communities in Prince William Sound, Alaska. Ecol Appl 6:828-841

> Wolfe D, Michel J, Hameedi MJ, Payne JR and others (1994) The fate of the oil spilled from the Exxon Valdez. Environ Sci Technol 28:560A-568A

Submitted: July 6, 2011; Accepted: November 22, 2011 Proofs received from author(s): February 6, 2012 